Volume 6

Number 1 Texas A\&M CLIP Symposium on

Copyright's Excess

Article 3

$10-1-2020$

\title{
Using the Lessons of Copyright's Excess to Analyze the Political Economy of Section 203 Termination Rights
}

Ann Bartow

University of New Hampshire School of Law, ann.bartow@law.unh.edu

Follow this and additional works at: https://scholarship.law.tamu.edu/journal-of-property-law

Part of the Intellectual Property Law Commons

\section{Recommended Citation}

Ann Bartow, Using the Lessons of Copyright's Excess to Analyze the Political Economy of Section 203 Termination Rights, 6 Tex. A\&M J. Prop. L. 23 (2020).

Available at: https://doi.org/10.37419/JPL.V6.11.3

This Symposia Article is brought to you for free and open access by Texas A\&M Law Scholarship. It has been accepted for inclusion in Texas A\&M Journal of Property Law by an authorized editor of Texas A\&M Law Scholarship. For more information, please contact aretteen@law.tamu.edu. 


\title{
USING The Lessons of Copyright's ExCESS to Analyze the Political Economy of Section 203 Termination Rights
}

\author{
By: Ann Bartow ${ }^{1}$
}

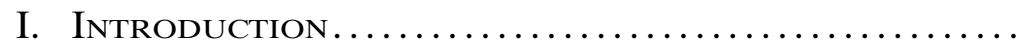

II. The Time for Overall Copyright Reform Is Nigh .................................... 24

III. The Current Approach to Termination Rights Desperately Needs Reform .................... 27

IV. Can't Stop the Section 203 Termination Rights: The Victor Willis Story ..................... 29

V. Are Sound Recordings Works for Hire?......... 31

VI. Applying the Lunney Lens .................... 34 A. The Special Case of Sound Recordings............ 35

VII. A Couple of Recommendations AND A Conclusion ...................................

\section{INTRODUCTION}

Glynn Lunney's recent book Copyright's Excess: Money and Music in the Recording Industry provides many important, even stunning insights about copyright law and policy, primarily from the standpoint of economic analysis. To highlight just one example of many, Lunney does an outstanding job assembling data to support a core assertionmore money does not mean more music. In fact, according to his research, more money empirically means less music. Consider the introduction to Chapter Seven, in which Lunney observes:

In the previous chapters, we found that for the recording industry from 1962 through 2015, copyright's fundamental premise did not hold. More copyright led to a sharp increase in revenues from the sale of recorded music, but more revenue did not lead to more and better music. To the contrary, it led to less. Moreover, the data reveals precisely why: as revenues increased, earnings for our top artists rose sharply; as they did, our top artists started producing fewer hit songs. Only when revenues and earnings began to fall in

\section{DOI: https://doi.org/10.37419/JPL.V6.I1.3}

1. Professor of Law and Director of the Franklin Pierce Center for Intellectual Property at the University of New Hampshire School of Law. The author thanks Glynn Lunney for writing this book, Saurabh Vishnubhakat for inviting me to participate in TAMU Law's symposium on this book, and Lauri Connolly for stellar administrative support and editorial assistance. This review essay is dedicated to Casey Bartow-McKenney, PhD. 
the post-file-sharing era did the productivity of our top artists begin to pick up again. ${ }^{2}$

He further claims that if musical artists retire after banking a specific amount of money, they very well may choose to work only as hard as accumulating that desired level of wealth requires. Lunney noted that if a copyright regime enabled an artist to earn that sum by recording fifty successful songs, then that artist might rationally decide to retire after recording and releasing fifty songs. If a copyright system enabled an artist to earn the desired sum of money for recording a single successful song, then that might be the only song the artist produces. ${ }^{3}$

It remains unclear whether motivating high-earning, successful artists to create more works (by shrinking their incomes), or motivating them to retire (by enhancing their incomes) to make room at the top for other artists is the way to increase the overall level of production of good music. The impact that current copyright laws have on the number of recording artists who are able to fully support themselves by authoring copyrighted sound recordings is similarly opaque. Yet without Lunney drawing attention to the economic dynamics of the music industry as he did, one might not even think of these questions, no less attempt a search for answers.

In the context of making policy recommendations, Lunney explained that copyright owners will perpetually lobby Congress to alter copyright laws to transfer wealth from consumers to themselves. ${ }^{4} \mathrm{He}$ noted: "Fortunately, in politics it is much easier to prevent Congress from acting than to get Congress to act." ${ }^{5} \mathrm{He}$ further (and very astutely) observed that copyright owners will also continually avail themselves of any venue available to them, including the courts. Additionally, they will try to persuade European actors to expand copyright, and then "argue harmonization or trade-related interests to persuade Congress to grant them the same protection in the United States." 6

\section{The Time for Overall Copyright Reform is Nigh}

One of the most important contributions that Copyright's Excess makes is to demonstrate very convincingly that copyright law as a whole needs fresh analysis and rethinking. It has been almost a quarter of a century since the United States Congress enacted the Digital Millennium Copyright Act, which among other initiatives established the "notice and take down" paradigm that provides a safe harbor from copyright infringement liability for website owners that remove mate-

2. Glynn Lunney, Copyright's Excess: Money and Music in the RecordING INDUSTRY 193 (2018).

3. Id. at $193-94$.

4. Id. at 197.

5. $I d$.

6. Id. 
rial that copyright holders allege to be an infringement. It has been over twenty years since passage of the Copyright Term Extension Act, which increased copyright terms retroactively as well as prospectively.

Supplementing Congressional action, mainly to wrangle doctrinal lapses and ambiguities, the United States Supreme Court has disrupted previous copyright law understandings in cases like: M.G.M. Studios v. Grokster, ${ }^{7}$ which added "inducing infringement" as a category of secondary liability for copyright infringement; Kirtsaeng $v$. John Wiley and Sons, Inc., ${ }^{8}$ which extended the "first sale doctrine" to copyrighted works lawfully made abroad; American Broadcasting Cos., Inc. v. Aereo, Inc., ${ }^{9}$ which expanded the definition of "public performance" by analogizing the Internet broadcasting of copyrightable audiovisual works to cable retransmission; and Star Athletica, LLC v. Varsity Brands, Inc. ${ }^{10}$ which established a new test for determining the copyrightability of pictorial, graphic, and sculptural works that are "useful articles." Parties who are unhappy with these jurisprudential developments want Congress to legislatively undo them. Parties that benefited from these changes want Congress to codify them by amending the Copyright Act. Lunney is correct to be concerned that some of these parties' lobbying initiatives will gain traction and change the law without considering how this alters incentives for various stakeholders.

There are other signs that pressure is building for significant new copyright law reforms as well. One powerful indication is that the American Law Institute ("ALI") is producing a Restatement of Copyright Law, ${ }^{11}$ something this author recommended in $2005^{12}$ and again in $2014 .{ }^{13}$ Given the controversy this project has engendered, ${ }^{14}$ ALI is unlikely to explicitly include Lunney's recommendations in any significant way within the rules of this Restatement. Though some invested parties accuse the drafters of promulgating radical change, the final version of the Restatement of Copyright is unlikely to be revolution-

7. See Metro-Goldwyn-Mayer Studios Inc. v. Grokster, Ltd., 545 U.S. 913 (2005).

8. See Kirtsaeng v. John Wiley \& Sons, Inc., 568 U.S. 519 (2013). (2014).

9. See American Broadcasting Companies, Inc. v. Aereo, Inc., 573 U.S. 431

10. See Star Athletica, L.L.C. v. Varsity Brands, Inc., 137 S. Ct. 1002 (2017).

11. See Restatement of the Law, Copyright, The AM. L. Inst., https://www.ali.org/ projects/show/copyright/ (last visited Aug. 31, 2019).

12. Ann Bartow, The Hegemony of the Copyright Treatise, 73 U. CIn. L. REv. 1, 3 (2004).

13. Ann Bartow, A Restatement of Copyright Law as More Independent and Stable Treatise, 79 Brook. L. Rev. 457, 498 (2014).

14. See e.g. Terry Hart, Clearing the Air on the ALI Copyright Restatement, CopyRIGHT All. Blogs (Jan. 19, 2018), https://copyrightalliance.org/ca_post/ali-copyrightrestatement/ [https://perma.cc/CR6X-EYP6]; Scott Alan Burroughs, ALI's Great Copyright Caper: Has The American Law Institute Been Hijacked by Big Tech?, ABOVE THE L. (Jan. 24, 2018, 6:15 PM), https://abovethelaw.com/2018/01/alis-greatcopyright-caper-has-the-american-law-institute-been-hijacked-by-big-tech/ [https:// perma.cc/MYA7-XJ82]. 
ary. It would be encouraging to find references to Lunney's research mentioned in appropriate related ALI commentaries, but we shall see if this happens.

Another barometric signal of copyright law change is the rampedup visibility and copyright advocacy of public interest NGOs such as the Electronic Frontier Foundation, ${ }^{15}$ Public Knowledge, ${ }^{16}$ the Authors Alliance, ${ }^{17}$ the Center for Democracy and Technology ${ }_{18}^{18}$ and the Organization for Transformative Works, ${ }^{19}$ which generally work to make information more accessible. While the NGOs define themselves as pro-consumer, they are sometimes accused of working on behalf of "big tech," which has a low barriers copyright agenda of its own.

Not all of the reforms proposed by these organizations will meet with Lunney's approval. For example, Public Knowledge is in favor of "extending full, federal copyright protection to pre-1972 sound recordings, including 95 year term limits [and] [s] upporting the creation of a federal public performance right for terrestrial AM/FM radio." 20 Lunney argues that the sound recording copyright should be abolished altogether. $^{21}$

Other NGO proposed initiatives are beyond the scope of Lunney's book. The Author's Alliance is in favor of enhancing the moral rights of authors through new statutory moral rights legislation. ${ }^{22}$ Public Knowledge advocates for changes to the Copyright Act's statutory damages regime, asserting:

When a single act may result in damages ranging between $\$ 200$ and $\$ 150,000$ per work infringed, legitimate activities both large and small are chilled. Whether an individual uploads a parody of a pop hit, a museum displays an exhibit of orphaned works, or a large company provides offsite data storage for its customers, each can be held hostage to potential damages awards that are orders of magnitude larger than any actual harm caused to a copyright holder. Threats of these astronomical damages can affect the landscape before any dispute even goes to trial, forcing settlements that pre-

15. See Elec. Frontier Found., https://www.eff.org/search/site/copyright [https:/ /perma.cc/LK5Q-GVJ5] (last visited Aug. 31, 2019) (search results for "copyright").

16. See Copyright Reform, Pub. KnowledGe, https://www.publicknowledge.org/ issues/copyright-reform/ [https://perma.cc/S562-6GRS] (last visited Aug. 31, 2019).

17. See About Us, Authors All., https://www.authorsalliance.org/about/ [https:// perma.cc/SH2H-97GD] (last visited Aug. 31, 2019).

18. See About CDT, CDT, https://cdt.org/about/ [https://perma.cc/GE8R-Q8EJ] (last visited Aug. 31, 2019).

19. See Legal Advocacy, Org. FOR Transformative Works, https://www.transformativeworks.org/legal/ [https://perma.cc/QS96-73ZU] (last visited Aug. 31, 2019).

20. See Music Licensing, Pub. Knowledge, https://www.publicknowledge.org/is sues/music-licensing [https://perma.cc/5WMV-HE33] (last visited Aug. 31, 2019).

21. See LunNeY, supra note 2, at 207-08.

22. U.S. Copyright Office Releases Report on Moral Rights, Authors All. (Apr. 29, 2019), https://www.authorsalliance.org/2019/04/29/u-s-copyright-office-releases-re port-on-moral-rights/ [https://perma.cc/GML3-TKKL]. 
vent new innovations from seeing the light of day. The United States should reexamine and reform its current system of statutory damages, taking into account the current state of technology and consumer uses, as well as specific circumstances that might call for mitigating damages. ${ }^{23}$

The Center for Democracy and Technology seems to concentrate on copyright law and policy developments in Europe, doing work that Lunney would likely be in favor of, but focusing on issues such as text and data mining in the Copyright Directive context. ${ }^{24}$ The Organization for Transformative Works centers its advocacy on fan fiction and fan culture and all related legal issues, including copyright law. ${ }^{25}$ The bedrock upon which its activism is built is a broad construction of fair use that supports authors who use existing works as the raw material for their own creative output. ${ }^{26}$ Lunney's views seem generally aligned with this approach: His data and conclusions are less relevant to "not for profit or commercial distribution" transformative works of fandom, which likely dominate the genre, than for profit seeking authors and intermediaries. However, his work still provides useful frameworks for analyzing pertinent economic and legal issues embedded within relationships between incentives and creative output in the context of fan works.

\section{The Current Approach to Termination Rights Desperately Needs Reform}

The most unnecessarily complicated right the Copyright Act provides for human authors ${ }^{27}$ is the right to unilaterally terminate a license (a.k.a a "grant") of copyrights after a fixed period of time. The theory behind allowing authors (or their statutory heirs if the author is deceased) to unilaterally terminate a license is to facilitate renegotiation of unfavorable terms and conditions when a work is commercially successful but the author is not sharing in the financial rewards. For example, someone who signs over the rights to a novel for $\$ 10,000$

23. Principles for a Balanced Copyright Policy, Pub. Knowledge (May 21, 2012), https://www.publicknowledge.org/documents/principles-for-a-balanced-copyright-pol icy [https://perma.cc/A4JP-VQM7].

24. CDT Joins Open Letter on Text and Data Mining Exception in EU Copyright Discussions, CDT (Jan. 16, 2019), https://cdt.org/insight/cdt-joins-open-letter-on-textand-data-mining-exception-in-eu-copyright-discussions/ [https://perma.cc/VP9KSMK8].

25. Legal, TransformativeWORKs.org, https://www.transformativeworks.org/ legal/ [https://perma.cc/UC3T-NUAX] (last visited Aug. 31, 2019).

26. $I d$.

27. Termination rights do not apply to works for hire. See U.S. Copyright OfFICE, Works MAdE FOR Hire 4 (2017) https://www.copyright.gov/circs/circ30.pdf [https://perma.cc/F4C6-6MZP]; see also Termination of Transfers and Licenses Under 17 U.S.C. \$203, U.S. Copyright OfFice, https://www.copyright.gov/docs/203.html [https://perma.cc/AW58-M2LD] (last visited Sept. 6, 2019); see also 17 U.S.C. § 203(a) (2012) 
today and then watches it generate hundreds of thousands or even millions of dollars in royalties for the publisher, can unilaterally terminate the agreement under Section 203 or 304(c) \& (d) if all the required conditions are met. After terminating the unfavorable license, the author can try to negotiate a better deal with either the same publisher or start fresh with a different one.

For copyrightable works created and fixed after the Copyright Act of 1976 took effect on January 1, 1978, the termination right is found in Section 203. It is unwaivable and empowers authors (or their statutory heirs if the author is deceased) to take free of licenses about thirty-five to forty years after the licenses were executed. The Copyright Act explains:

Termination of the grant may be effected at any time during a period of five years beginning at the end of thirty-five years from the date of execution of the grant; or, if the grant covers the right of publication of the work, the period begins at the end of thirty-five years from the date of publication of the work under the grant or at the end of forty years from the date of execution of the grant, whichever term ends earlier. ${ }^{28}$

For works predating the enactment of Section 203, human authors (or their statutory heirs if the author is deceased) can only terminate a license when they affirmatively renew their copyrights, and then only if they have not waived this right, as many authors did. ${ }^{29}$ These termination rights are found in Sections 304(c) and (d) of the Copyright Act. Termination of the grants covered by these sections "may be effected at any time during a period of five years beginning at the end of fifty-six years from the date copyright was originally secured, or beginning on January 1, 1978, whichever is later." These termination provisions will eventually sunset in 2034 when all the copyrights secured on December 31, 1977, or earlier, finally exceed fifty-six years of age.

When evaluating the significance of statutory termination rights, one can credit Congress with looking out for authors who might otherwise be completely cut out of the financial windfall garnered by the distribution of a popular and successful creative work. Yet Congress made exercising termination rights so complicated and difficult that it is hard to view this putative solicitude as sincere. Licenses for works covered by Section 304 almost always contain waivers of termination rights, and the courts have held that this type of waiver is enforceable against the author, though generally not against the author's heirs.

Congress clearly acted in the best interests of authors by making Section 203 termination rights unwaivable. An author or her statutory

28. 17 U.S.C. $\S 203(a)(3)$ (2012).

29. Many, in fact probably close to all, pre-1978 licenses required authors to waive their Section 304 termination rights. The courts held these waivers enforceable against the authors, though not against their heirs. See Stewart v. Abend, 495 U.S. 207, 219-20 (1990). 
heirs can exercise Section 203 termination rights even if the express terms of the written license say otherwise, and even if the author received additional compensation for agreeing to the waiver. However, authors who do not know about termination rights, or do not understand that they are unwaivable, cannot exercise them.

Any commercial publisher with access to legal advice likely knows about termination rights and understands that they are unwaivable. Yet typical copyright licenses are very likely to contain a provision that claims the agreement is in effect for the entire duration of the copyright. This is to trick authors out of asserting their termination rights. Few authors will know that termination rights are unwaivable regardless of contract language to the contrary, if they are even aware of their termination rights at all. The license holder has no obligation to inform authors about termination rights and every incentive to try to obscure their very existence. License holders do not want to have to renegotiate licenses that enrich them or risk losing control over valuable works.

Authors who endeavor to terminate licenses need solid, competent legal representation to stand a chance at accomplishing termination. They must serve termination notices on the correct parties, in the correct form, and at the correct time. ${ }^{30}$ Failure to do so may result in closure of a termination window and the continuation of a disadvantageous license through the end of its specified term, which is often the entire duration of the relevant copyright. Even authors who navigate all the required steps necessary for the termination of a license may be unable to successfully complete the termination due to legal pushback from the license holder.

\section{Can't Stop the Section 203 Termination Rights: The Victor Willis Story}

The first wave of Section 203 terminations began in 2013, thirty-five years after the first wave of copyright licenses after the Copyright Act of 1976 took effect in 1978. Among those authors seeking termination was Victor Willis, who had co-written thirty-three songs, some of which were made famous by the musical group, The Village People, with whom Willis performed, dressed in a police uniform. These songs included "YMCA," "Go West," and "In the Navy." The license holder, Can't Stop Music, fought back aggressively. Can't Stop Music sued Willis to try to prevent termination of the agreement he had

30. See generally Adam Holofcener, The Right to Terminate: A Musicians' Guide to Copyright Reversion, Future of Music CoAL. (Feb. 16, 2012), https://futureofmu sic.org/article/fact-sheet/right-terminate-musicians \% E2\% $80 \% 99$-guide-copyright-re version [https://perma.cc/4PGT-V8MX]. 
signed, alleging that Mr. Willis, as one of at least three credited coauthors, could not unilaterally serve a notice of termination. ${ }^{31}$

Can't Stop Music additionally argued that the songs were "works made for hire" 32 because Victor Willis was the company's employee. Stewart L. Levy, a lawyer representing Can't Stop Music, was quoted as saying at the time: "We hired this guy. He was an employee. We gave them the material and a studio to record in and controlled what was recorded, where, what hours and what they did." ${ }^{33}$ This claim was later dropped ${ }^{34}$ when Can't Stop Music conceded that all of the original copyright registration filings answered "no" to the question on the form that asked whether it was a work for hire. ${ }^{35}$

Victor Willis, a very successful songwriter, only knew that he had termination rights because his spouse, an attorney familiar with copyright law, notified him. ${ }^{36} \mathrm{He}$ was also lucky enough to have half a million dollars at his disposal to spend on lawyers. Ultimately, he prevailed in court and was able to regain control over his copyrights. $\mathrm{He}$ also successfully sued to remove one of the purported co-authors from some of the disputed songs ${ }^{37}$ and for reimbursement of his attorney's fees. ${ }^{38}$ In 2015, District Court Judge Barry Ted Moskowitz granted Willis $\$ 527,236$ to cover his attorney's fees and $\$ 3,034$ in costs incurred during the multiyear copyright litigation he endured to successfully exercise his termination rights. Judge Moskowitz wrote:

The Court does find . . . that a grant of attorney's fees would advance considerations of compensation and deterrence and would

31. Scorpio Music S.A. v. Willis, No. 11-cv-1557 BTM (RBB), 2012 WL 1598043, at $* 2$ (S.D. Cal. May 7, 2012).

32. U.S. Copyright OfFICE, supra note 27, at 2.

33. Larry Rohter, A Copyright Victory, 35 Years Later, N.Y. Times (Sept. 10, 2013), https://www.nytimes.com/2013/09/11/arts/music/a-copyright-victory-35-years-la ter.html [https://perma.cc/KR3B-EMSY].

34. Eriq Gardner, Music Publisher Drops Key Claim in 'Y.M.C.A.' Copyright Termination Lawsuit, Hollywood ReP. (Mar. 22, 2012, 4:44 PM), https://www.hol lywoodreporter.com/thr-esq/ymca-village-people-lawsuit-copyright-termination-3033 77 [https://perma.cc/NHR9-9DHY].

35. $I d$.

36. Rohter, supra note 33. See also George Varga, Victor Willis on Life \& Music, Post-Village People, San Diego Union-Trib. (Aug. 2, 2015, 6:00 AM), https://www. sandiegouniontribune.com/entertainment/music/sdut-victor-willis-interview-2015aug 02-story.html [https://perma.cc/M2HC-NCYQ]; Eriq Gardner, Village People Singer Victor Willis Breaks Silence about Copyright Lawsuit Win, Hollywood ReP. (May. 11, 2012, 12:04 PM), https://www.hollywoodreporter.com/thr-esq/village-peoplevictor-willis-copyright-lawsuit-323489 [https://perma.cc/WS3K-DS8P].

37. Eriq Gardner, Jury Decides Village People 'Y.M.C.A.' Songwriter has 50 Percent Song Share, Hollywood REP. (Mar. 05, 2015, 8:39 AM), https://www.hollywood reporter.com/thr-esq/jury-decides-village-people-ymca-779420 [https://perma.cc/ MLV2-VX4E].

38. Diane Bell, "YMCA" Writer Wins Court Battle, San Diego Union-Trib. (Sept. 18, 2015, 5:29 PM), https://www.sandiegouniontribune.com/entertainment/tv/ sdut-village-people-ymca-victor-willis-lawsuit-fees-won-2015sep18-story.html [https:// perma.cc/WF8H-ECPQ]. 
further the purposes of the Copyright Act. Section 203, providing for the termination of transfers of copyrights, was designed to "safeguard [ ] authors against unremunerative transfers" and address "the unequal bargaining position of authors, resulting in part from the impossibility of determining a work's value until it has been exploited." H.R. Rep. No. 94-1476, at 124 (1976), reprinted in 1976 U.S.C.C.A.N. 5659, 5740. Willis is an author who incurred significant attorney's fees in trying to get back what he transferred to Plaintiffs, parties with superior bargaining power, decades ago. An award of attorney's fees is justified to encourage authors like Willis to assert their rights to regain their copyright interests and to deter production companies and other transferees of copyright from attempting to interfere with those rights. ${ }^{39}$

This termination rights saga had a happy ending for Victor Willis but it is not at all clear that other authors will experience similar triumphs over seasoned, well-funded corporate intermediaries anxious to retain control over profitable creative works and are even more determined not to cut authors into the revenue streams that these works generate. Composers like Willis may have an advantage because they tend to write musical compositions alone or in small groups, which may give them more persuasive claims to authorship. Recording artists who turn musical compositions into sound recordings, however, may produce their works in studios in collaboration with producers, engineers, and other musicians. This complicates their claims to authorship and therefore to termination rights.

\section{Are Sound Recordings Works for Hire?}

As of this writing, a group of sound recording artists lead by John Waite is suing Sony and UMG over their refusals to honor termination notices for sound recordings they authored. The basis of the refusals is primarily an assertion that these songs were recorded as "works for hire" and therefore ineligible for Section 203 terminations by the authors. ${ }^{40}$ The musicians' complaint alleges in pertinent part:

Waite, Ely, and hundreds of other recording artists, have served Notices of Termination upon UMG pursuant to the provisions set forth

39. Scorpio Music S.A. v. Willis, No. 11-cv-1557 BTM (RBB), 2012 WL 1598043 at 7-8 (S.D. Cal. Sept. 15, 2015).

40. Sony and UMG are also alleging that because the recording artists had entered into licenses through "loan out" companies for tax purposes, they were not "executed by the author" within the meaning of Section 203(a) which sets out "conditions for termination." See generally Scott Alan Burroughs, Terminators, Mount Up!: Section 203 and Copyright Recovery (Part 1), Aвove the L. (May 15, 2019 3:41 PM), https://abovethelaw.com/2019/05/terminators-mount-up-section-203-and-copyright-re covery-part-i/ [https://perma.cc/C8VT-UJ4J]; see also Aaron J. Moss \& Kenneth Basin, Copyright Termination and Loan-Out Corporations: Reconciling Practice and Policy, 3 Harv. J. Sports \& ENT. L. 55 (2012) (addressing question of whether the use of loan out companies renders the sole company owner's creative output works for hire for copyright law purposes). 
in 17 U.S.C. $\S 203$, but UMG has routinely and systematically refused to honor them. These refusals are made, in every instance, on similar legal grounds, the first and foremost of which is UMG's position that the sound recordings created by recording artists under contract with UMG (or its affiliated or predecessor companies) are "works made for hire," and, therefore, not part of the subject matter of $\S 203$. UMG claims that the recordings are works made for hire because of contractual language that is found in every UMG recording agreement. As a result of UMG's policy, UMG has refused to acknowledge that any recording artist has the right to take over control of the sound recordings or enter into an agreement with a different label for the exploitation of recordings, after the effective date of termination. In many instances, UMG has continued to exploit the recordings after the effective date, thereby engaging in willful copyright infringement of the United States copyright in those recordings. As a result of UMG's actions, UMG has effectively stymied any chance that the class plaintiffs have of entering into a new agreement with a third party, or even exploiting the recordings themselves, as is their right. As a result, these actions by UMG have effectively destroyed the very salability of the posttermination rights in the recordings that the Copyright Act expressly guarantees. ${ }^{41}$

The "work for hire" assertion that was abandoned by the music companies in the Victor Willis litigation is apparently the primary response that Sony and UMG use to justify their refusals to acknowledge termination notices for sound recordings. The companies apparently planned well ahead when they drafted contracts in the late 1970s and early 1980s, using "work for hire" language in licenses for just this thirty-five-years-in-the-future eventuality. In fact, thirtyfive years later their prescience is notable. Meanwhile, the musicians (and sadly, their representatives who negotiated licenses for them) probably did not understand the ultimate end to which this language was going to be deployed. Even if they had been aware of the work for hire exemption from Section 203 termination rights, they might not have believed that using the words "work for hire" in a written agreement would magically transmogrify a work that was not a work for hire under the applicable statutory provisions of the Copyright Act into one that is. ${ }^{42}$ In 1999, record companies engineered the addition of "sound recording" to the list of copyrightable work categories that can potentially be works for hire if the other conditions are met. This amendment to the Copyright Act was then quickly repealed. As Mary LaFrance noted: "In late 1999, Congress amended the definition of "works made for hire" in $\S 101$ of the Copyright Act to make explicit

41. Waite v. UMG Recordings, Inc., No. 1:19-cv-01091, 2019 WL 469770, at 2-3 (S.D.N.Y. Feb. 5, 2019).

42. See Mary LaFrance, Authorship and Termination Rights in Sound Recordings, 75 S. CAL. L. Rev. 375 (2002); see also Chase A. Brennick, Termination Rights in the Music Industry: Revolutionary or Ripe for Reform?, 93 N.Y.U. L. REv. 786 (2018). 
its intent to include sound recordings as a category of works eligible for this status. The amendment was repealed with retroactive effect less than a year later. All this happened-pardon the expression-in record time." 43

The music at issue will only be deemed works for hire if Sony and UMG can convince one or more federal judges either that the authors of these sound recordings were employees, or that the songs fit within one of the categories of works that can be works for hire when created by an independent contractor with a writing that expressly states the songs are works for hire. Proving that the authors were employees may be difficult for Sony and UMG. As Ryan Vacca noted several years ago, the most important "Reid factors" used to assess whether someone is an employee for work for hire purposes weigh in favor of authors of sound recordings as independent contractors, in part because they received advances and royalties rather than paychecks. ${ }^{44}$ Another commentator noted that they generally did not have health insurance, retirement benefits, or even administrative support. ${ }^{45}$

Sony and UMG have a somewhat better shot at convincing a court that independent contractors created the disputed songs as works for hire. This approach requires a writing that says the songs are works for hire, which the companies apparently finagled by inserting those words into the licenses they persuaded the authors to sign, as explained above. However, it also requires proof that the works themselves were "specially ordered or commissioned for use as a contribution to a collective work, as a part of a motion picture or other audiovisual work, as a translation, as a supplementary work, as a compilation, as an instructional text, as a test, as answer material for a test, or as an atlas." 46 Some observers are dubious about this prospect. ${ }^{47}$

However, Mary La France has argued that the music companies may be able to convince a court that the sound recordings were a contribution to a collective work, writing:

[A]s a matter of plain-language statutory interpretation, the typical sound recording consists of multiple musical performances, and is therefore "collective." Thus, the "collective works" category is literally broad enough to include such sound recordings, even without

43. LaFrance, supra note 42, at 375.

44. Ryan Vacca, Work Made for Hire-Analyzing the Multifactor Balancing Test, 42 Fla. St. U. L. ReV. 197, 238-39 (2014).

45. Moral Rights, Termination Rights, Resale Royalty and Copyright Term: Hearing Before the Subcomm. on Courts, Intellectual Prop. And the Internet of the H. Comm. on the Judiciary, 113th Cong. 4 (2014) (statement of Casey Rae, Vice President for Policy and Education, Future of Music Coalition).

46. 17 U.S.C. $\$ 101$ (2012); See also U.S. Copyright Office, Works Made fOR HiRe 2 (2017) https://www.copyright.gov/circs/circ30.pdf [https://perma.cc/QL79KMXT].

47. Brennick, supra note 42. 
any specific mention thereof in the legislative history. Accordingly, there is a strong argument, based on the literal language of the statute, that the inclusion of "a contribution to a collective work" in the list of works eligible for work-made-for-hire status makes the typical commercial sound recording eligible for such status. ${ }^{48}$

To quote her again: "[t]wo questions remain: First, under current law, who is the author of a sound recording? Second, regardless of the answer to the first question under current law, who should be the author of a sound recording?" 49 If federal courts presented with this issue decide that Mary LaFrance is correct about the statutory meaning of "collective works," the music companies are the authors of numerous commercial sound recordings. This would be the end of Section 203 termination rights for many sound recording artists. Answering the second question brings us back to Lunney's many useful insights in Copyright's Excess.

\section{Applying the LunNey Lens}

Echoing the introduction to Copyright's Excess, the overarching questions this part of the essay considers are: do Section 203 termination rights encourage the creation of new works? And do Section 203 termination rights promote the broader dissemination of existing works of authorship? Lacking the rich empirical data Lunney collected, all that is reasonably possible is to sketch out some possible answers and hope that someday Lunney or some other interested party collects relevant information and crunches the numbers.

Initially, one seemingly obvious point still bears stating: If authors are unaware of their termination rights, those rights will have no impact on their creative production whatsoever. Were termination rights an incentive for more (or better) music for Victor Willis? Clearly not because Victor Willis did not know they existed when he was writing lyrics for songs that became wildly successful. He learned of them only after marrying a lawyer who understood copyright law. ${ }^{50}$ The Copyright Office could launch an education campaign to inform authors about termination rights. Content holding intermediaries would forcefully oppose this because they benefit tremendously from author ignorance about this aspect of copyright law.

If authors feel confident that they can reclaim their copyrights about thirty-five years after they license them away, this may provide them with an incentive to create more works. Or it may not. If regaining control of copyrights gives authors positive feelings about creating, then maybe that will increase their enthusiasm for working. But if all it does is increase the money they receive for existing works, the effect

48. LaFrance, supra note 42 , at 389.

49. Id. at 376.

50. Rohter, supra note 33. 
on their output could be neutral or even negative. Lunney makes a very convincing case in Chapter Five that in the context of sound recordings, more money did not mean more music, and in Chapter Six that more money actually meant less music in some cases. Alternatively, if it appears to authors that Section 203 termination rights can be exercised only after protracted and expensive legal battles, and maybe not even then, they will not seem much like "rights" and will not provide much in the way of incentives to authors at all. Authors who feel badly treated by licensees who attempt to deprive them of their termination rights may even sour on the music industry and stop creating new works altogether.

The dissemination analysis is more positive. If authors can predictably and efficiently reclaim their copyrights using Section 203 termination rights, this almost certainly would lead to the broader dissemination of existing works. After termination, authors can choose different intermediaries to partner with, move from exclusive to nonexclusive licenses, or engage in distributive acts themselves. Authors can leverage their control of the copyrights in commercially successful works to obtain support for less economically flourishing works.

A third related concern is the effect of termination rights on the companies that license the copyrights from authors. So far, Section 203 termination notices seems to bring out the worst in corporate content holding intermediaries. They are fighting savagely to avoid losing control of commercially successful works and probably also over (so far) unsuccessful works as well. In addition to aggressive litigation, they also engage in dirty tricks, such as adding fake co-authors to copyright registrations so that they can still have some control over works that are the subjects of successful terminations. ${ }^{51}$ While there is no reason to believe that abolishing Section 203 termination rights would result in better treatment of authors, the negative impacts of fights over termination rights need to be monitored.

\section{A. The Special Case of Sound Recordings}

Copyright's Excess focuses on sound recordings, and Lunney suggests that perhaps sound recordings should not even be copyrightable in Chapter Seven. As explained above, recording artists who work collaboratively may have a more difficult time being recognized as authors for the purpose of Section 203 termination rights than composers and perhaps other categories of authors as well. Lunney makes a persuasive case against sound recording copyrights, and if Section 203 termination rights are not available to them, it is not clear that commercial recording artists have much to lose if they are abolished.

51. Gardner, supra note 37. 
VII. A Couple of Recommendations And A Conclusion

If the political will exists to provide authors with more robust termination rights, Congress should make them available sooner and make the process of termination far simpler and easier to exercise. This sort of change will do nothing to solve the problem Lunney identifies of excess incentives for the most popular artists and may actually exacerbate the difficulty as authors who can count on revenue streams from recaptured copyrights may be even less likely to produce new works. It would, however, provide average or even marginal authors with more incentives to create, if they believe that they will have an opportunity to get out from under unfavorable licensing agreements for unexpectedly popular or "sleeper" works.

Alternatively, Congress can simply make already nonwaivable Section 203 termination rights mandatory. It can amend the Copyright Act to require that all copyright licenses lapse after some number of years, and the copyrights automatically revert to the human authors or their statutory heirs. ${ }^{52}$ This is not a radical proposition, though content holding intermediaries will paint it as such. It is simply a means to better effectuate the goal of returning copyrights to authors so that they (or their statutory heirs) can predictably reap some of the rewards of their labors even after signing and enduring unfavorable contracts.

Whatever path is chosen, some change needs to happen. What Victor Willis endured to exercise his termination rights was deeply unfair. That multiyear, multicourt, multilawyer dispute diverted a lot of time and money that could have been used more productively. And his case seems like a best-case scenario compared to the scorched earth Waite et al v. Sony and BMG litigation. If copyright law is going to offer termination rights to authors, the copyright industries must somehow be forced to stop thwarting the process. Lunney is correct that radical reform of the Copyright Act is needed, and Section 203 termination rights provide a stunning example of why.

52. This is not intended as an endorsement of the Copyright Act's "statutory heirs" paradigm. "Statutory heirs" are very problematic construct, but that is a topic for another day. See Tonya M. Evans, Statutory Heirs Apparent?: Reclaiming Copyright in the Age of Author-Controlled, Author-Benefitting Transfers, 297 W. VA. L. REV. 119 (2016). 